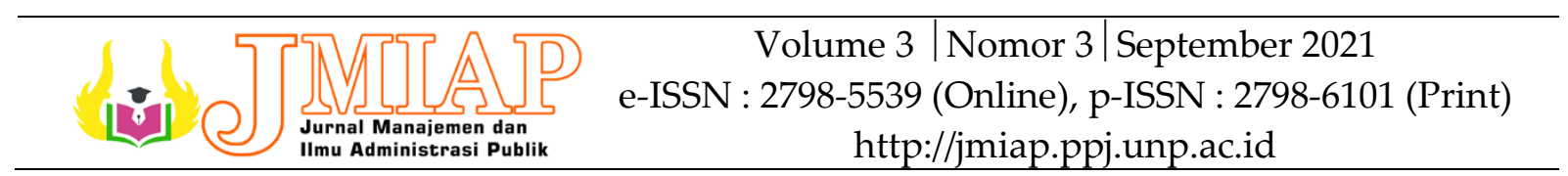

\title{
INOVASI PELAYANAN PUBLIK MELALUI SISTEM APLIKASI POTENSI INVESTASI (SIAPI) DI DINAS PENANAMAN MODAL DAN PELAYANAN TERPADU SATU PINTU KOTA DUMAI
}

\author{
Maysara $^{1(a)}$, Hasim As'ari'(b) \\ ${ }^{1,2}$ Jurusan Ilmu Administrasi Publik, Universitas Riau \\ ${ }^{a)}$ maysaraa26@gmail.com, ${ }^{b}$ hasim_asari99@yahoo.co.id
}

\begin{tabular}{l}
\multicolumn{1}{c}{$\begin{array}{c}\text { INFORMASI } \\
\text { ARTIKEL }\end{array}$} \\
\hline Article History: \\
Dikirim: \\
01-08-2021 \\
Selesai Revisi: \\
08-09-2021 \\
Diterbitkan Online: \\
30-09-2021 \\
\hline
\end{tabular}

Kata Kunci:

Inovasi, Pelayanan Publik, Aplikasi SIAPI

Keywords:

Innovation, Public Service, SIAPI Application

\section{Corresponding Author:}

maysaraa26@gmail.com

DOI:

https://doi.org/10.24036/jmiap.v3i3.290
Pelayanan publik merupakan tanggung jawab pemerintah kepada warganya yang diamanatkan oleh Undang-Undang Dasar 1945. Salah satu instansi pemerintah penyedia pelayanan publik yaitu Dinas Penanaman Modal Dan Pelayanan Terpadu Satu Pintu Kota Dumai. DPMPTSP Kota Dumai sedang gencar melakukan inovasi untuk meningkatkan pelayanan. Inovasi yang dimaksud yaitu Aplikasi Potensi Investasi (SIAPI) untuk kemudahan berinvestasi. Tujuan penelitian ini untuk mengetahui bagaimana inovasi pelayanan publik melalui SIAPI di DPMPTSP Kota Dumai dan faktor penghambat yang mempengaruhi penerapan SIAPI. Penelitian ini menggunakan teori inovasi Rogers yang memiliki lima indikator, yaitu keunggulan relatif, kesesuaian, kerumitan, kemungkinan dicoba, dankemudahan diamati. Jenis penelitian yang digunakan yaitu penelitian kualitatif dengan pendekatan fenomenologi. Pengumpulan data yang diperlukan baik data primer maupun data sekunder dari hasil wawancara, observasi, dokumentasi, kemudian dianalisis sehingga ditarik kesimpulan dari masalah penelitian. Temuan dari penelitian ini yaitu inovasi belum berjalan dengan baik. Faktor yang menghambat penerapan SIAPI yaitu sosialisasi, half implemented, SDM dan anggaran.

ABSTRACT
Public service is the government's responsibility to its citizens as mandated
by the 1945 Constitution. One government agency that provides public
services is the Department of Investment and One Stop Integrated Service,
Dumai City. Dumai City DPMPTSP is aggressively making innovations to
improve services. The innovation in question is the Investment Potential
Application (SIAPI) for ease of investing. The purpose of this study was to
determine how public service innovation through SIAPI in DPMPTSP
Dumai City and the inhibiting factors that affect the implementation of
SIAPI. This research uses Rogers' innovation theory which has five
indicators, namely relative advantage, compability, complexity, triability,
and observability. The type of research used is qualitative research with a
phenomenological approach. Collecting data required both primary data
and secondary data from the results of interviews, observation,
documentation, then analyzed so that conclusions are drawn from the
research problem. The finding of this research is that innovation has not
been going well. Factors that hinder the adoption of SIAPI are
socialization, half implemented, HR and budget.

Public service is the government's responsibility to its citizens as mandated by the 1945 Constitution. One government agency that provides public services is the Department of Investment and One Stop Integrated Service, Dumai City. Dumai City DPMPTSP is aggressively making innovations to improve services. The innovation in question is the Investment Potential Application (SIAPI) for ease of investing. The purpose of this study was to determine how public service innovation through SIAPI in DPMPTSP SIAPI. This research uses Rogers' innovation theory which has five indicators, namely relative advantage, compability, complexity, triability, and observability. The type of research used is qualitative research with a phenomenological approach. Collecting data required both primary data and secondary data from the results of interviews, observation, documentation, then analyzed so that conclusions are drawn from the research problem. The finding of this research is that innovation has not socialization, half implemented, HR and budget. 


\section{PENDAHULUAN}

Pelayanan publik merupakan hak konstitusi warga dan masyarakat, dimana hal ini diperkuat oleh UU No.25 Tahun 2009 tentang Pelayanan Publik. Namun persoalan yang terjadi mengenai pelayanan publik tak kunjung usai seperti menurut riset Ombudsman RI pada tahun 2017 terdapat berbagai permasalahan dasar dalam pemberian pelayanan publik di Indonesia yang perlu menjadi sorotan. Pertama, masih terdapat instansi yang belum memiliki aturan yang jelas dalam menyediakan pelayanan, seperti prosedur pelayanan yang rumit dan berbelit-belit sangat menyusahkan masyarakat sebagai pengguna pelayanan publik.

Kedua, kurangnya efisiensi waktu sehingga pelayanan terkesan sangat lamban dan memakan waktu berjam-jam. Ketiga, keterampilan petugas pelayanan tidak sesuai dengan pekerjaan dan tergolong masih rendah untuk memberikan pelayanan yang baik. Keempat, masih terdapat banyaknya petugas yang menunjukkan sikap, cara berbicara dan memberikan pelayanan yang tidak ramah. Kelima, masih adanya instansi-instansi yang belum menggunakan sarana dan prasarana yang layak dan sesuai dengan perkembangan zaman, hal ini juga menjadi penyebab kurang efektif dan efisiennya pelayanan publik.

Tingkat kesadaran masyarakat terhadap pelayanan publik saat ini semakin meningkat sehingga penyelenggara layanan dan pemerintah dituntut untuk memberikan pelayanan yang berkualitas dan tentunya bermutu tinggi sehingga dapat memberikan pengaruh bukan hanya pada kepuasan masyarakat namun salah satunya juga dalam potensi investasi di suatu daerah. Di era pembangunan saat ini investasi sangat dimanfaatkan oleh pemerintah khususnya pemerintah daerah guna meningkatkan pembangunan. Maka dari itu kemudahan pelayanan, sarana dan prasarana yang memadai akan menjadi daya tarik bagi para investor dalam berinvestasi. Jika pelayanan masih rumit, tidak rensponsif dan berbelit-belit tentu saja mengurangi minat para investor untuk berinvestasi.

Setiap daerah berlomba-lomba memperbaiki pelayanan publik guna memacu dan memaksimalkan potensi-potensi yang ada di daerahnya masing-masing. Salah satunya yaitu Kota Dumai yang berada di Provinsi Riau Indonesia. Letak Kota Dumai sangat strategis yaitu berada di Selat Rupat dan berbatasan dengan Selat Malaka yang merupakan salah satu lintas pelayaran tersibuk dunia, menjadikan Kota Dumai berada pada Jalur perdagangan Internasional. Seiring berjalannya waktu Kota Dumai tumbuh dan berkembang menjadi kota Jasa dan Industri yang berada di pesisir Provinsi Riau. Posisi Dumai yang strategis sangat mendukung kegiatan ekspor dan impor sehingga berpeluang terciptanya kawasan perdagangan bebas antarnegara di Kota Dumai.

Potensi-potensi Kota Dumai baik dari segi letak yang strategis, potensi SDA maupun SDM merupakan daya tarik tersendiri untuk menarik investasi di Kota Dumai. Investasi merupakan hal penting dalam meningkatnya pembangunan dan perkembangan Kota Dumai.

Faktor yang dapat dimanfaatkan untuk mendukung investasi salah satunya yaitu faktor teknologi. Kecanggihan teknologi informasi dan komunikasi adalah wujud dari era globalisasi yang di rasakan seluruh dunia. Informasi dan komunikasi merupakan komoditi yang sangat berharga di era milenialisasi untuk dikuasai dalam rangka peningkatan daya saing pemerintah daerah secara berkelanjutan.

Pada kondisi eksisting saat ini seluruh daerah dilanda pandemic Covid-19 tidak terkecuali Kota Dumai. Kota Dumai pertama kali mengkonfirmasi adanya kasus positif Covid-19 pada Mei 2020. Upaya pencegahan banyak dilakukan seperti pembatasan sosial berskala besar, penerapan protokol kesehatan seperti memakai masker jika keluar rumah, mencuci tangan dan menjaga jarak dengan orang lain. Sehingga pemerintah daerah dituntut untuk menciptakan trobosan baru melalui program-program yang dapat mengurangi kontak secara langsung agar memutus rantai penyebaran Covid-19. Hal ini mendorong munculnya sebuah inovasi pelayanan yang menuntut adanya perbaikan serta perubahan khususnya bagi pemerintah dalam menyelenggarakan pelayanan publik.

Seperti hasil penelitian dari beberapa penelitian terdahulu berikut ini, Diah Nur Fitriana (2014) tentang Inovasi Pelayanan Publik BUMN (Studi Deskriptif tentang Inovasi Boarding Pass System dalam Meningkatkan Kualitas Pelayanan Kereta Api PT KAI di Stasiun Gubeng Surabaya), yakni menemukan bahwa Inovasi boarding pass system di Stasiun Gubeng dapat dikatakan cukup baik dalam memberikan pelayanan publik yang assurance.

Selanjutnya, yaitu penelitian (Rizvanda Meyliano Dharma Putra, 2018) tentang Inovasi 
Pelayanan Publik Di Era Distrupsi (Studi Tentang Keberlanjutan Inovasi E-Health Di Kota Surabaya) bahwa penelitian ini belum berjalan dengan baik dan memiliki persamaan dengan topic yang diteliti penulis yaitu Persamaannya terletak pada tema inovasi pelayanan publik yang memanfaatkan media elektronik.

Serta hasil penelitian dari (Regita Vania Ronnyta, 2020) tentang Inovasi Pelayanan Perizinan melalui Si-Imut Pada Dinas Penanaman Modal dan Pelayanan Terpadu Satu Pintu Kota (DPMPTSP) Kota Semarang menemukan bahwa Aplikasi SI-IMUT merupakan solusi dalam suatu permasalahan yang dialami DPMPTSP Kota Semarang untuk meningkatkan pelayanan publik. Kegiatan pelayanan publik yang dilakukan pegawai DPMPTSP Kota Semarang menjadi lebih efektif dan efisien.

(Ida Wantri Hastuti, Susi Sulandari, 2018) Analisis Inovasi Pelayanan Perizinan Jemput Bola Di Dinas Penanaman Modal dan Pelayanan Terpadu Satu Pintu (DPMPTSP) Kabupaten Semarang. Penelitian ini menemukan Faktor pendorong dari inovasi jemput bola adalah dorongan politik, tekanan ekonomi dan peningkatan efisiensi, tekanan untuk meningkatkan kualitas pelayanan. Faktor penghambat terdiri dari keengganan menutup program yang gagal, teknologi ada, terhambat budaya dan penataan organisasi, tidak ada penghargaan atau insentif, ketidakmampuan menghadapi resiko dan perubahan, anggaran jangka pendek dan perencanaan, budaya risk aversion.

Maka dari itu beberapa penelitian terdahulu tersebut menjadi referensi bagi penulis untuk melakukan penelitian ini, diharapkan dapat menjadi evaluasi bagi pemerintah dalam mewujudkan pemerintahan yang bersih dan efektif melalui penyelenggara pemerintahan yang profesional, partisipatif, aspiratif dan transparansi.

Dengan banyaknya kemajuan yang terjadi di Kota Dumai, pemerintah Kota Dumai dituntut untuk menyelenggarakan pelayanan publik yang dapat disesuaikan dengan perkembangan zaman sehingga pelayanan yang diterima masyarakat cepat dan responsif. Hal utama yang dapat dijadikan acuan responsivitas penyedia pelayanan publik terhadap masyarakat adalah munculnya sebuah inovasi pelayanan. Inovasi menjadi hal yang wajib dipenuhi oleh pemerintah mengingat tingginya kesadaran masyarakat untuk mendapatkan haknya. Selain itu inovasi juga sebagai tuntutan responsivitas, akuntabilitas, transparansi, dan prinsip-prinsip good governance lainnya, sehingga dapat meningkatkan kinerja organisasi publik.

Dinas Penanaman Modal dan Pelayanan Terpadu Satu Pintu (DPMPTSP) Kota Dumai merupakan salah satu instansi yang memiliki peran penting dalam mewujudkan pelayanan publik. Tujuan didirikannya DPMPTSP Kota Dumai adalah untuk penyelenggara pelayanan perizinan dan non perizinan yang prima dan satu pintu. Hal tersebut diharapkan dapat mendorong terciptanya iklim usaha yang kondusif bagi penanaman modal dan investasi dalam rangka pemberdayaan ekonomi masyarakat Kota Dumai. Sehubungan dengan pesatnya pertumbuhan Kota Dumai, Pemerintah Kota Dumai berupaya menggali potensi dan peluang investasi di Kota Dumai agar investor dalam negeri maupun luar negeri minat berinvestasi di Kota Dumai sesuai dengan visi yang telah ditetapkan.

Pemerintah Kota Dumai melalui DPMPTSP Kota Dumai sedang gencar-gencarnya melakukan trobosan inovatif dalam rangka meningkatkan pelayanan publik. Trobosan inovatif tersebut ditujukan untuk memberikan pelayanan prima, transparan dan profesional terhadap masyarakat. Inovasi dilakukan oleh DPMPTSP Kota Dumai dimulai dari dikembangkannya pola perizinan antar jemput. Salah satunya inovasi yang dikeluarkan oleh DPMPTSP Kota Dumai yaitu dibidang investasi.

Inovasi ini dikeluarkan oleh DPMPTSP Kota Dumai dengan tujuan promosi kepada masyarakat maupun pelaku usaha untuk mau berinvestasi dan mempermudah calon investor menanamkan modal di Dumai. Masyarakat atau calon investor hanya menghubungi DPMPTSP Kota Dumai melalui sebuah aplikasi sehingga masyarakat tidak perlu bersusah payah datang ke lokasi. Hal ini dilakukan supaya image di masyarakat terkait mengurus izin tidaklah sulit maupun mahal. Sehingga masyarakat dalam mengurus izin tidak mengunakan jasa calo yang dapat merugikan masyarakat itu sendiri.

Aplikasi ini bukan hanya bentuk dari kemudahan pelayanan yang di berikan oleh Pemerintah, namun juga sebagai bentuk promosi kepada masyarakat, investor dan calon investor. Latar belakang dibuatnya aplikasi ini berdasarkan fakta bahwa belum maksimalnya pemanfaatan potensi-potensi Kota Dumai. 
Salah satu contoh, peluang investasi di Bidang Perkebunan. Produksi komoditi perkebunan Kota Dumai saat ini masih berupa bahan baku, contohnya untuk kelapa sawit hanya berupa Tandan Buah Segar (TBS), kelapa butiran, karet ojol, dan pinang berupa biji kering. Namun kemanfaatan yang diperoleh petani tidak sepadan dengan harapan investasi pada perkebunan tersebut, mengingat harga TBS yang sering turun dibandingkan harga produksinya.

Inovasi terkait kemudahan investasi yang diluncurkan oleh DPMPTSP Kota Dumai ini diberi nama "SIAPI" yang merupakan singkatan dari "Sistem Aplikasi Potensi Investasi" yang dapat diunduh di Google Playstore. Aplikasi ini di luncurkan oleh Walikota Dumai Pada tanggal 29 Oktober 2019. Penggunaan aplikasi ini diatur dalam Peraturan Walikota Dumai Nomor 24 Tahun 2019 tentang Kewajiban Laporan Investasi Melalui Sistem Aplikasi Potensi Investasi. jumlah pengguna aplikasi SIAPI hanya berjumlah 28 orang dari awal peluncurannya sampai pada tahun 2021. Bahkan ditemukan adanya pegawai DPMPTSP Kota Dumai yang tidak mengetahui aplikasi SIAPI yang di operasikan ini.

Perbedaan penelitian terdahulu yaitu penelitian ini mengkaji tentang inovasi pelayanan publik dengan aplikasi sebagai objeknya yang merupakan program baru untuk menunjang kualitas pelayanan di Dinas Penanaman Modal dan Pelayanan Terpadu Satu Pintu (DPMPTSP) Kota Dumai. Sehingga dapat diketahui bahwa tujuan penelitian ini untuk melihat apakah aplikasi SIAPI memiliki keunggulan dibandingkan dengan sistem yang diterapkan sebelumnya. Melihat bagaimana kesesuaian aplikasi SIAPI dengan kengininan pemerintah Kota Dumai untuk meningkatkan pelayanan pada era digitalisasi. Kerumitan dan kendala apa saja yang ditemui dalam penerapan aplikasi SIAPI sebagai penunjang pelayanan kepada masyarakat. Namun dalam pelaksanaannya, masih terdapat permasalahanpermasalahan yang menghambat penerapan aplikasi SIAPI ini.

Permasalahan selanjutnya yaitu terkait kesiapan DPMPTSP Kota Dumai dalam pelaksanaan aplikasi SIAPI yaitu belum menyiapkan sumber daya manusia yang ahli dalam mengoperasikan sistem online konsultasi sehingga masih membutuhkan bantuan dari partner yang bekerja sama dengan DPMPTSP Kota Dumai. Selain itu masalah yang di temukan terkait aplikasi SIAPI yaitu aplikasi sulit di temukan baik di Google Playstore. Jika kita mengetik kata SIAPI banyak aplikasiaplikasi lain yang muncul karena lebih populer atau lebih sering di unduh yang membuat sulit untuk menemukan aplikasi SIAPI ini. Sehingga jika masyarakat ingin mengunduh aplikasi SIAPI harus mencari dengan teliti. Dengan banyaknya aplikasi yang ada di Google Playstore dan Appstore kemungkinan untuk menemukan aplikasi ini sangat kecil. Fitur-fitur yang disediakan di dalam aplikasi SIAPI ini masih sederhana, serta tampilan di dalam aplikasi kurang menarik sehingga monoton untuk dilihat. Penelitian ini bertujuan untuk mengetahui dan menganalisis inovasi pelayanan publik melalui sistem aplikasi potensi investasi (SIAPI) di Dinas Penanaman Modal dan Pelayanan Terpadu Satu Pintu Kota Dumai dan mengidentifikasi faktor penghambat inovasiSIAPI di Dinas Penanaman Modal dan Pelayanan Terpadu Satu Pintu Kota Dumai.

Menurut (Sadu, 2001) dalam (Hardiyansyah, 2018) mendefinisikan pelayanan publik sebagai pemberian jasa baik oleh pemerintah, pihak swasta, ataupun pihak swasta atas nama pemerintah, guna memenuhi kebutuhan dan kepentingan masyarakat. Sedangkan (Thoha, 2001) beropini bahwa pelayanan publik diartikan sebagai pemberian layanan demi memenuhi keperluan orang atau masyarakat yang memiliki kepentingan pada organisasi tersebut sesuai dengan prosedur yang telah ditetapkan oleh organisasi tersebut.

Menurut (Bharata, 2004) dan (Agustina, 2016) unsur-unsur pelayanan publik yang harus dipenuhi, antara lain:

a. Penyedia layanan yaitu pihak yang memberikan pelayanan tertentu kepada konsumen, baik dalam bentuk penyediaan dan penyerahan barang atau jasa;

b. Penerima layanan, yaitu yang menerima berbagai pelayanan dari para penyedia layanan atau biasa disebut dengan konsumen (customer);

c. Jenis layanan, yaitu bentuk layanan yang diberikan penyedia layanan untuk memenuhi kebutuhan pihak yang membutuhkan layanan;

d. Kepuasan pelanggan, merupakan tujuan utama adanya layanan tersebut. Untuk mengetahui kepuasan yang diperoleh pelanggan yakni dengan melihat kualitas barang atau jasa yang mereka dapatkan. 
Setiap penyelenggara pelayanan publik sebaiknya memiliki standar pelayanan, sehingga dapat dijadikan jaminan berupa kepastian baik bagi pemberi dan penerima layanan. Standar pelayanan dapat diartikan sebagai pedoman dalam menyelenggarakan pelayanan publik yang harus dipatuhi oleh pemberi dan juga penerima pelayanan. MENPAN Nomor 63/2003 tentang Pedoman Umum Penyelenggaraan Pelayanan Publik, standar pelayanan harus meliputi:

a. Prosedur Pelayanan. Prosedur pelayanan yang dilakukan dalam hal ini yaitu kemudahan dalam pemberian pelayanan kepada masyarakat serta kemudahan dalam rangka memenuhi persyaratan-persyaratan pelayanan.

b. Waktu Penyelesaian. Waktu yang ditetapkan sejak saat pengajuan permohonan sama dengan penyelesaian pelayanan sesuai dengan lamanya waktu pelayanan masing-masing yang telah ditetapkan.

c. Biaya Pelayanan. Biaya atau tarif pelayanan termasuk rincian yang ditetapkan dalam proses pemberian pelayanan, haruslah secara wajar serta terperinci dan tidak melanggar ketentuan-ketentuan yang ada.

d. Produk Pelayanan. Hal ini berkaitan dengan kenyataan dalam pemberian pelayanan yaitu hasil pelayanan sesuai dengan yang telah ditentukan serta terbebas dari kesalahan teknis.

e. Sarana dan Prasarana. Penyediaan sarana dan prasarana yang memadai oleh penyelenggara pelayanan publik. Hal ini berkaitan dengan tersedianya perangkat penunjang pelayanan yang memadai seperti meja, kursi dan lainnya. Serta kenyamanan dan kemudahan dalam mendapatkan pelayanan.

Rogers, 1983 dalam (Sholahuddin, 2017) mengartikan inovasi sebagai inovasi, ide atau praktik dari seorang individu atau komunitas. Inovasi telah memasuki ranah persepsi, memungkinkan individu, komunitas, dan sistem sosial memiliki persepsi dan perspektif yang berbeda ketika melihat inovasi. Bisa dikatakan inovasi mungkin sudah ditemukan sejak lama, namun masih ada sebagian orang lain yang masih menganggap inovasi sebagai hal baru, sehingga masih memungkinkan bagi mereka untuk mengatakan sesuatu tersebut adalah inovasi.
Menurut (Mulgan, Albury \& Kurniawan, 2015) dijelaskan bahwa Inovasi yang berhasil merupakan kreasi dan implementasi dari adanya proses, produk layanan hingga metode pelayanaan baru yang merupakan hasil pengembangan nyata dalam hal efisiensi, efektivitas dan kualitas hasil. Dalam hal ini inovasi proses bermula dari adanya gerakan pembaruan kualitas yang berkelanjutan dan berpedoman pada kombinasi perubahan aturan, organisasi, dan kebijakan yang dibutuhkan dalam berinovasi. Inovasi dalam prosedur pelayanan yaitu pembaruan dalam hal berinteraksi dengan penerima layanan atau cara baru dalam memberikan pelayanan. Inovasi dalam strategi atau kebijakan mengacu pada visi misi, tujuan dan strategi serta melihat realita sebagai alasannya. Manusia memutuskan untuk berinovasi karena adanya dorongan dari suatu pihak atau melihat pihak lain sudah melakukan inovasi.

Inovasi dalam penerapannya memiliki atribut-atribut didalamnya yang dapat dijadikan indikator-indikator pengukuran keberhasilan dari sebuah inovasi. (Rogers, 2003) (Pangestu, 2016) menguraikan atribut inovasi antara lain:

a. Keunggulan Relatif (Relative Advantage). Sebuah inovasi mempunyai keunggulan dan nilai lebih jika dibandingkan dengan sebelumnya. Nilai kearuan selalu adan dan melekat dalam inovasi yang menjadi ciri khas yang menjadi pembeda dengan yang lain.

b. Kesesuaian (Compability). Inovasi memiliki sifat kesesuaian atau kompatibel dengan inovasi yang diganti. Hal ini bermaksud agar inovasi sebelumnya tidak serta merta dibuang begitu saja selain karena faktor biaya yang sedikit, inovasi yang lama menjadi bagian dari proses transisi ke inovasi yang baru. Selain itu juga dapat memudahkan proses adaptasi serta pembelajaran terhadap inovasi dengan lebih tepat.

c. Kerumitan (Complexity). Dengan sifatnya yang baru maka inovasi mempunyai tentunya memiliki tingkat kerumitan yang lebih tinggi jika dibandingkan dengan inovasi sebelumnya. Meskipun demikian karena inovasi menawarkan cara yang baru serta lebih baik maka tingkat kerumitan ini umumnya tidak menjadi masalah yang sangat penting.

d. Kemungkinan Coba (Triability). Inovasi dapat diterima apabila telah teruji dan 
terbukti mempunyai keunggulan atau nilai lebih jika dibandingkan dengan inovasi sebelumnya. Sehingga produk inovasi harus melalui fase uji publik yang mana setiap orang atau semua pihak mempunyai kesempatan untuk menguji kualitas inovasi tersebut.

e. Kemudahan diamati (Observability). Sebuah inovasi dapat diamati dari sisi bagaimana ia bekerja dan menghasilkan sebuh hal yang lebih baik. Dengan atribut ini maka inovasi merupakan cara baru utuk menggantikan cara lama dalam memproduksi atau mengerjakan sesuatu.

Meskipun demikian, inovasi memiliki dimensi geofisik yang dapat menempatkannya baru pada suatu tempat namun bisa menjadi sesuatu yang lama dan biasa terjadi di tempat lainnya.

\section{METODE PENELITIAN}

Pada penelitian ini peneliti menggunakan jenis penelitian kualitatif dengan pendekatan studi kasus yang memiliki sifat analisis deskriptif. Penelitian kualitatif dilakukan dengan mengumpulkan berbagai informasi kemudian diolah dengan mengajukan berbagai pertanyaan dan prosedur, pengumpulan data yang spesifik yang didapatkan dari para partisipan, peneliti menggunakan analisis data secara induktif yang dimulai dari tema khusus ke tema yang umum serta menafsirkan makna dari data.

Analisis deskriptif merupakan metode dalam meneliti status kelompok, suatu kondisi, sikap serta pandangan terhadap suatu fenomena yang terjadi dalam masyarakat dan mengurutkan data sesuai dengan situasi yang sedang terjadi. Selanjutnya, pendekatan studi kasus merupakan salah satu pendekatan dalam metode penelitian kualitatif. Pada pendekatan ini, penelitian dilakukan dengan cara mengeksplorasi kehidupan nyata, sistem terbatas kontemporer atau berbagai sistem terbatas melalui pengumpulan data yang secara detail serta melibatkan berbagai sumber informasi atau sumber lainnya seperti pengamatan, wawancara, audiovisual, dokumen dan berbagai laporan yang ada.

Penelitian ini menggunakan metode kualitatif karena dengan pendekatan studi kasus peneliti dapat lebih melihat secara mendalam dan menganalisis inovasi pelayanan publik melalui Sistem Aplikasi Potensi Investasi (SIAPI) di Dinas Penanaman Modal dan
Pelayanan Terpadu Satu Pintu Kota Dumai. Dilihat dari wilayahnya, penelitian studi kasus ini hanya meliputi daerah atau subjek yang sempit namun ditinjau dari objek atau sifat penelitian maka penelitian studi kasus dapat lebih mendalam.

Salah satu tujuan penelitian ini menggunakan analisis deskriptif adalah agar peneliti dapat mengungkapkan serta menggambarkan fakta, fenomena, variabel dan keadaan yang terjadi saat penelitian berlangsung dengan menyuguhkan apa yang sebenarnya terjadi tanpa menambah dan mengurangi agar dapat dipercaya serta tidak menimbulkan kesalahan perspektif. Penelitian ini dilakukan di Kota Dumai dengan lokus DPMPTSP yang merupakan salah satu pelaksana penyelenggaraan pelayanan di Kota Dumai. Alasan peneliti memilih lokasi penelitian karena Dinas Penanaman Modal dan Pelayanan Terpadu Satu Pintu Kota Dumai memiliki inovasi program di bidang pelayanan yang ditujukan untuk mempermudah masyarakat dan juga para investor untuk menanamkan modalnya di DPMPTSP Kota Dumai, dan juga dalam rangka meningkatkan potensi investasi di Kota Dumai sebagaimana yang diketahui bahwa Kota Dumai merupakan kota urutan ketiga tujuan investasi.

Analisis data dalam penelitian ini diawali dari mengumpulkan data mentah yang telah di peroleh pada saat observasi, wawancara dan survei. Data mentah yang diperoleh baik dalam bentuk tertulis, soft copy dan rekaman ataupun catatan pada saat penelitian, kemudikan dikumpulkan untuk di satukan menjadi sebuah data dan informasi yang lebih sederhana untuk dibaca dan dipahami. Hasil pengumpulan data wawancara dan survei yang diperoleh disusun berdasarkan pedoman penggalian data yang menjadi instrumen dalam penelitian yang telah disusun terlebih dahulu. Kemudian hasil wawancara diidentifikasikan sesuai dengan pertanyaan yang diajukan oleh peneliti kepada beberapa narasumber yang sudah ditetapkan menjadi informan penelitian. Dalam penelitian ini, dipilih informan-informan yang mengetahui tentang inovasi pelayanan publik melalui Sistem Aplikasi Potensi Investasi (SIAPI) di Dinas Penanaman Modal dan Pelayanan Terpadu Satu Pintu Kota Dumai. Yaitu Kepala Bidang Perencanaan dan Pengembangan Iklim, Kepala Bidang Penyelenggaraan Pelayanan Perizinan dan Non Perizinan, Kasi Deregulasi Penanaman Modal DPMPTSP Kota Dumai 
serta investor sebagai pengguna aplikasi SIAPI. Informan atau subjek penelitian dapat memahami dan menguasai masalah serta bersedia memberikan informasi yang lengkap dan akurat terkait data yang dibutuhkan untuk penelitian ini. Berikut merupakan analisis data yang digunakan peneliti dalam melaksanakan penelitian tentang inovasi pelayanan publik melalui Sistem Aplikasi Potensi Investasi (SIAPI) di Dinas Penanaman Modal dan Pelayanan Terpadu Satu Pintu Kota Dumai.

\section{HASIL DAN PEMBAHASAN}

Aplikasi SIAPI (Aplikasi Potensi Investasi) merupakan inovasi teknologi pelayanan di bidang investasi berupa perangkat elektronik dengan sistem online yang memiliki tujuan untuk mempermudah pemberian layanan bagi masyarakat Kota Dumai yang lebih efektif dan efisien, serta dapat di akses di mana saja dan kapan saja, sehingga masyarakat tidak perlu datang ke kantor dinas untuk mendapatkan pelayanan dari aparatur pelayanan Dinas Penanaman Modal dan Pelayanan Terpadu Satu Pintu Kota Dumai.

Sebagaimana yang sudah dijelaskan pada latar belakang tentang pelaksanaan inovasi pelayanan publik melalui Sistem Aplikasi Potensi Investasi (SIAPI) di Dinas Penanaman Modal dan Pelayanan Terpadu Satu Pintu Kota Dumai yang berjalan kurang maksimal. Berbagai hambatan dan tantagan ditemukan dalam proses penerapan aplikasi SIAPI yang dilakukan oleh Dinas Penanaman Modal dan Pelayanan Terpadu Satu Pintu Kota Dumai.

Inovasi adalah sesuatu yang baru pada kehidupan seseorang atau suatu sistem sosial. Rogers (1983) (Sholahuddin, 2017) menilai inovasi adalah sebuah ide, praktik, atau objek yang dipersepsikan sebagai sesuatu yang baru oleh individu. Inovasi juga dapat terjadi di ruang lingkup pelayanan publik. Kebutuhan akan pelayanan publik yang sangat besar mengharuskan pemerintah Kota Dumai untuk berinovasi demi mempermudah masyarakat untuk memperoleh pelayanan. Selain memajukan pelayanan, Pemerintah Kota Dumai juga di tuntut untuk mengembangkan potensi yang ada di daerahnya, dimana hal tersebut merupakan tanggung jawab Dinas Penanaman Modal dan Pelayanan Terpadu Satu Pintu Kota Dumai. Ide dan gagasan yang dihasilkan oleh Dinas Penanaman Modal dan Pelayanan Terpadu Satu Pintu tersebut yang berikutnya disebut dengan inovasi pelayanan publik yang bertujuan untuk mempermudah pelayanan dan meningkatkan investasi di Kota Dumai.

Untuk mengetahui inovasi pelayanan publik melalui sistem aplikasi potensi investasi di Dinas Penanaman Modal Dan Pelayanan Terpadu Satu Pintu Kota Dumai, peneliti menggunakan 5 indikator inovasi yang dikemukakan oleh Rogers dalam Pangestu, antara lain sebagai berikut: Keunggulan relative (Relative Advantage); Kesesuaian (Compability); Kerumitan (Complexity); Kemungkinan coba (Triability); dan Kemudahan diamati (Observability).

\section{Keunggulan Relative (Relative Advantage)}

Dari indikator ini, peneliti akan melihat keunggulan atau nilai lebih apa yang dimiliki inovasi yang diterapkan di DPMPTSP Kota Dumai. Dalam hal ini, keunggulan atau nilai lebih penerapan inovasi SIAPI di DPMPTSP Kota Dumai yaitu dapat dilihat dalam bentuk sistem penerapannya. Bagaimana sistem yang diterapkan sebelum adanya inovasi, sistem yang diterapkan setelah adanya inovasi.

Berdasarkan hasil wawancara dapat diketahui bahwa sebelumnya DPMPTSP Kota Dumai menggunakan sistem manual. Masyarakat harus datang langsung ke kantor DPMPTSP Kota Dumai yang tentunya memakan waktu yang lebih lama dan juga memerlukan biaya transportasi. Namun demi mendukung kemudahan pelayanan dan segala bentuk perizinan, DPMPTSP Kota Dumai bertransformasi dengan memanfaatkan kecanggihan teknologi yang berupa sistem berbasis online.

Untuk mendukung segala bentuk perizinan DPMPTSP Kota Dumai menggunakan Online Single Submission (OSS) yaitu perizinan berusaha yang diterbitkan oleh Lembaga OSS untuk dan atas nama menteri, pimpinan lembaga, gubernur, atau bupati/wali kota kepada pelaku usaha melalui sistem elektronik yang terintegrasi, OSS ini merupakan sistem dari pusat yang harus diterapkan seluruh DPMPTSP yang ada di seluruh Indonesia. Kemudian ada SIPERI yaitu sistem yang dari Dinas Penanaman Modal dan Pelayanan Terpadu Kota Dumai yang merupakan sistem untuk segala bentuk perizinan yang tidak ada didalam OSS. Inovasi SIPERI ini diciptakan untuk meningkatkan kualitas pelayanan publik, SIPERI ini dioperasikan melalui web yang di buat oleh DPMPTSP Kota Dumai untuk mendukung pelayanan perizinan. 
Sistem yang digunakan berikutnya yaitu SIAPI berupa aplikasi yang dibuat oleh DPMPTSP Kota Dumai sebagai aplikasi potensi investasi. Untuk kemudahan layanan dan sebagai promosi kepada masyarakat tentang investasi Kota Dumai, dan untuk menarik minat berinvestasi di Kota Dumai. Ciri khasnya dari aplikasi SIAPI ini untuk mempertegas pemberian insentif dan kemudahan dalam berinvestasi. Melihat kondisi Kota Dumai yang merupakan kota perdagangan dan industri yang memiliki perusahaan-perusahaan besar maupun perusahaan kecil dan UMKM.

Sebagai sebuah inovasi, aplikasi SIAPI memiliki nilai kebaruan yang menjadi ciri yang membedakan dengan yang lainnya. aplikasi ini memiliki ciri khas untuk mempertegas pemberian insentif yang memudahkan masyarakat dalam berinvestasi. Dengan adanya inovasi SIAPI, masyarakat hanya perlu membuka aplikasi sehingga lebih memudahkan masyarakat dalam mendapatkan informasi dengan cepat hanya dengan melalui smartphone yang dimilikinya. Dengan adanya aplikasi SIAPI, keunggulan lain yang didapatkan masyarakat dengan adanya sistem aplikasi ini yaitu dengan fitur-fitur yang tertera di dalam aplikasi, maka masyarakat dapat melihat beberapa informasi terkait perkembangan dan nilai investasi di Kota Dumai. Sehingga membuka peluang dan dapat menarik minat dari calon investor untuk menanamkan modalnya di Kota Dumai.

Bukan hanya itu dengan adanya aplikasi SIAPI tentunya juga dapat membantu para pelaku usaha dan UMKM serta masyarakat dengan melihat informasi yang disediakan di dalam fitur aplikasi SIAPI. Kesempatan kerja tentunya juga akan terbuka lebar untuk masyarakat. Dengan melihat informasi dan data yang disediakan di dalam aplikasi SIAPI, masyarakat akan mengetahui adanya perusahan-perusahaan baru sehingga membuka peluang kerja bagi masyarakat. Dengan adanya sistem yang diterapkan oleh DPMPTSP Kota Dumai, masyarakat tidak perlu lagi bersusah payah datang berulang kali ke Dinas Penanaman Modal dan Pelayanan Terpadu Kota Dumai. Misalnya untuk mengurus izin, masyarakat hanya tinggal mengklik website SIPERI ataupun OSS. Sedangkan untuk mendapatkan informasi tentang investasi, masyarakat hanya mendownload aplikasi SIAPI di Playstore. Aplikasi SIAPI ini menyediakan beragai fitur yang dapat digunakan masyarakat sebagai sarana memperoleh informasi.

\section{Kesesuaian (Compability)}

Inovasi ini menyesuaikan dengan kebutuhan masyarakat sesuai dengan perkembangan zaman yang sudah canggih. Inovasi teknologi ini diharapkan dapat menarik minat masyarakat untuk beralih dari pelayanan manual ke pelayanan online yang lebih memberikan banyak manfaat kepada masyarakat salah satunya lebih efektif dan efisien. Inovasi teknologi yang dikatakan berhasil yaitu inovasi yang dapat menarik masyarakat untuk beralih dari pelayanan manual ke pelayanan online. Jika tidak, maka inovasi tidak akan berfungsi dengan baik karena masyarakat tidak tertarik untuk menggunakannya. Adanya aplikasi ini juga untuk menunjukkan kepada masyarakat tentang kemudahan layanan dan kemudahan mendapatkan informasi sesuai dengan perkembangan era digitalisasi saat ini.

Sehingga masyarakat mengetahui DPMPTSP Kota Dumai sebagai organisasi perangkat daerah yang sangat loyal dalam melayani masyarakat. Agar tidak ada lagi pandangan di masyarakat yang berasumsi bahwa pengurusan izin, investasi dan pelayanan lainnya rumit dan mempersulit masyarakat. Adanya aplikasi SIAPI yang digunakan oleh DPMPTSP Kota Dumai semata-mata untuk mempermudah pemberian layanan kepada masyarakat. Pelayanan yang diberikan akan lebih efisien bagi masyarakat karena akan lebih cepat dan tentunya juga hemat biaya dan hemat waktu.

Meskipun sudah menggunakan sistem yang berbasis teknologi tetapi pihak Dinas Penanaman Modal dan Pelayanan Terpadu Satu Pintu Kota Dumai tidak menghilangkan sistem pelayanan secara manual. Karena pihak DPMPTSP Kota Dumai memaklumi bahwa belum tentu semua masyarakat paham menggunakan sistem yang berbasis teknologi. Jika adanya masyarakat yang belum mengetahui tentang adanya aplikasi SIAPI yang di terapkan oleh DPMPTSP Kota Dumai, masyarakat akan diberi arahan oleh pegawai untuk mendownload aplikasi SIAPI karena di dalam aplikasi tersebut terdapat sumber informasi yang nantinya akan dibutuhkan oleh masyarakat tersebut. Sehingga masyarakat tidak perlu mendatangi DPMPTSP Kota Dumai berulang kali hanya untuk menanyakan syaratsyarat atau informasi lainnya. Meskipun 
menggunakan teknologi, masih terdapat proses yang memiliki kesesuaian dengan proses pelayanan pada saat manual. Masyarakat nantinya tetap harus mendatangi DPMPTSP Kota Dumai untuk menunjukkan keaslian syarat-syarat untuk di cek dan di pastikan kebenarannya. Sehingga meminimalisir terjadinya penipuan.

Namun, masih banyak kekurangan dari sistem yang ada dalam aplikasi SIAPI. fiturfitur di dalam aplikasi SIAPI masih sederhana dan belum menerapkan sistem otomatis pada bagian konsultasi dengan admin. Kebutuhan masyarakat yang terus berubah sesuai perkembangan zaman menuntut pemerintah memberikan pelayanan yang lebih inovatif, efektif dan efisien. Yang mana pada era digitalisasi ini, maysarakat sebagai pengguna layanan mengharapkan sistem yang dengan cepat menjawab atau memberikan informasi terhadap apa yang dibutuhkan.

Meskipun masyarakat tidak perlu mendatangi DPMPTSP Kota Dumai berulang kali untuk menanyakan syarat-syarat atau informasi lainnya. Namun sistem yang diterapkan setelah adanya aplikasi SIAPI tetap mengharuskan masyarakat atau pengguna aplikasi melakukan penyerahan berkas secara manual. Sehingga hal tersebut dirasa belum optimal, karena maysarakat atau pengguna layanan mengharapkan proses pelayanan yang lebih efisien dan efektif tanpa harus datang ke Dinas Penanaman Modal dan Pelayanan Terpadu Satu Pintu Kota Dumai.

\section{Kerumitan (Complexity)}

Karena sifatnya yang baru maka inovasi mempunyai tingkat kerumitan yang lebih tinggi dibandingkan dengan sebelumnya. Karena sebuah inovasi menawarkan cara yang lebih baru dan lebih baik. Namun, meskipun sudah mengusung teknologi dalam hal memaksimalkan pelayanan dengan menciptakan aplikasi SIAPI ini, DPMPTSP Kota Dumai tetap menerapkan pelayanan secara konvensional untuk mendukung pelaksanaan aplikasi ini dengan mengharuskan masyarakat atau pengguna aplikasi untuk melakukan penyerahan berkas secara manual.

Meskipun sudah ada aplikasi SIAPI tetapi pelayanan atau proses administrasi tetap dilakukan secara konvesional atau dapat dikatakan penyerahan berkas-berkas dan persyaratan tetap dilakukan secara langsung. Sehingga fungsi teknologi yang diharapkan dapat mempermudah pelayanan belum mampu dilakukan, sehingga menjadi salah satu kerumitan dalam penerapan aplikasi SIAPI ini. Selain itu, setelah aplikasi ini dapat diakses oleh masyarakat terdapat permasalahan baru bagi masyarakat yang ingin mengoperasikan aplikasi atau pun ketika akan mendownload aplikasi SIAPI. DPMPTSP Kota Dumai.

Kesimpulan dari penjelasan di atas adalah bahwa keberlangsungan aplikasi SIAPI dipengaruhi oleh ketersediaan anggaran Dinas Penanaman Modal dan Pelayanan Terpadu Satu Pintu Kota Dumai. Tidak adanya anggaran maka penerapan aplikasi tidak akan berjalan optimal.

\section{Kemungkinan coba (Triability)}

Aplikasi SIAPI yang diterapkan DPMPTSP Kota Dumai sudah dijadikan sistem yang akan diterapkan secara permanen di DPMPTSP Pintu Kota Dumai. Berbagai apresiasi di dapatkan dengan diterapkannya aplikasi SIAPI. Bahkan dari pengguna-pengguna pada masa uji coba aplikasi. Masyarakat menyampaikan apresiasi dengan mengatakan terbantu dengan adanya aplikasi. Masyarakat menjadi mudah dalam memperoleh data dan informasi yang diperlukan.

Pada masa uji coba, Walikota Dumai memberi apresiasi kepada Dinas Penanaman Modal dan Pelayanan Terpadu Satu Pintu Kota Dumai. Adanya aplikasi SIAPI ini memberikan kemudahan bagi masyarakat untuk mendapatkan akses informasi terkait investasi. Walikota juga memberikan saran agar aplikasi ini tidak sebagai sumber informasi saja. Akan tetapi beliau berharap bahwa aplikasi ini terus di jalankan dan adanya pembaruan-pembaruan yang dapat lebih memudahkan masyarakat. Jadi koordinasi yang dilakukan dengan pihak KOMINFO juga memberi lampu hijau terkait aplikasi SIAPI. Respon positif terhadap aplikasi SIAPI menjadi pendukung aplikasi ini untuk tetap dilanjutkan. Mengingat dan menimbang dengan kebutuhan masyarakat yang terus meningkat dan menyesuaikan dengan perkembangan zaman. Aplikasi SIAPI dirasa sebagai hal yang patut dicoba untuk diterapkan demi mempermudah memberikan layanan bagi masyarakat.

\section{Kemudahan diamati (Observability)}

Aplikasi ini merupakan peniruan dari aplikasi yang di terapkan oleh daerah lain. Di daerah lain perkembangan teknologi sangat 
dimanfaatkan oleh pemerintahnya. Kemudahan akses dimanapun dan kapanpun menjadi latar belakang bagi pemerintah daerah lain untuk memanfaatkan teknologi secara maksimal.

Dari study banding yang dilakukan oleh Kepala Bidang Perencanaan dan Pengembangan Iklim Penanaman Modal DPMPTSP Kota Dumai melalui diklat kepemimpinan yang diikutinya di Kota Bandung, beliau mendapatkan motivasi untuk membuat sebuah inovasi untuk memudahkan pelayanan. Beliau melihat betapa mudahnya orang-orang yang ia temui di Kota Bandung untuk mengakses pekerjaan salah satunya menggunakan aplikasi e-kinerja sehingga memotivasi beliau untuk membuat terobosan baru yang dapat memudahkan pekerjaan di Dinas Penanaman Modal dan Pelayanan Terpadu Satu Pintu Kota Dumai dan juga sebagai kemudahan layanan untuk masyarakat Kota Dumai.

Dari sanalah muncul ide untuk membuat inovasi pelayanan yang berkemungkinan menjadi peluang bagi DPMPTSP Kota Dumai dengan harapan inovasi tersebut dapat berhasil di terapkan di Kota Dumai yaitu dapat meningkatkan investasi dan perekonomian masyarakat Kota Dumai. Informasi yang didapatkan dari kunjungan ke Kota Bandung tersebut coba di wujudkan DPMPTSP Kota Dumai dalam bentuk aplikasi. Melihat kebermanfaatan dan benefit yang didapatkan di masa yang akan datang dari inovasi berupa aplikasi tersebut. Jika inovasi tersebut diterapkan di Kota Dumai maka akan membuka potensi dari segi investasi yang dapat meningkatkan perekonomian Kota Dumai.

Hal ini menunjukkan bahwa inovasi berupa aplikasi SIAPI ini merupakan hal baru yang diterapkan di DPMPTSP Kota Dumai namun merupakan inovasi lama yang sudah lebih dulu diterapkan oleh daerah lain. Dari studi banding secara tidak langsung memberikan kesadaran kepada DPMPTSP Kota Dumai bahwa pentingnya memberikan kemudahan pelayanan kepada masyarakat. Selain untuk memenuhi kebutuhan masyarakat juga dapat memberikan keuntungan bagi Kota Dumai.

Sebelumnya DPMPTSP Kota Dumai sudah lebih dulu menerapkan SIPERI (Sistem Perizinan) sebagai wujud e-government. Namun SIPERI belum berbentuk aplikasi, hanya sebuah sistem yang dapat di akses melalui website. SIPERI sendiri hanya aplikasi seputar perizinan. Dengan adanya pengetahuan melalui studi banding, maka DPMPTSP Kota Dumai baru terfikir untuk membuat sistem pelayanan baru berupa aplikasi untuk memaksimalkan potensi investasi di Kota Dumai. Dengan harapan inovasi pelayanan baru tersebut dapat memberikan efisiensi dan efektifitas kepada masyarakat.

\section{Faktor Penghambat Inovasi Program SIAPI Di Dinas Penanaman Modal dan Pelayanan Terpadu Satu Pintu Kota Dumai}

1) Sosialisasi

Sosialisasi langsung kepada masyarakat belum pernah dilakukan karena terkendala anggaran pengadaan sosialisasi. Sosialiasi yang belum maksimal tersebut mengakibatkan banyak masyarakat yang belum mengetahui tentang aplikasi SIAPI. Meskipun telah dilakukan sosialisasi melalui berita, tidak semua masyarakat berminat membaca berita online. Sedangkan minat masyarakat di zaman ini yaitu bermain sosial media. Namun sosial media milik DPMPTSP Dumai tidak dimanfaatkan untuk mempromosikan aplikasi SIAPI. Hal ini sangat mempengaruhi implementasi dari inovasi teknologi pelayanan ini.

\section{2) Half Implemented}

Implementasi aplikasi SIAPI masih pada tahap half implemented atau belum sempurna, aplikasi SIAPI harus terus di upgrade program agar akhirnya dapat memenuhi kebutuhan masyarakat secara menyeluruh. Aplikasi SIAPI masih terkesan sederhana, dimana aplikasi SIAPI hanya berupa penyedia informasi saja. Hal ini terlihat dari Implementasi yang belum sempurna atau half implemented sangat berpengaruh terhadap keberhasilan implementasi aplikasi SIAPI.

Sebaiknya pihak DPMPTSP Kota Dumai melakukan evaluasi terhadap aplikasi buatannya ini, sehingga tujuan dari adanya pemangkasan birokrasi dapat berjalan dengan hadirnya aplikasi tersebut melalui cara memperbaki isi dari aplikasi SIAPI. Hal ini juga bertujuan agar terdapat output dari aplikasi SIAPI, misalnya berupa pengumpulan berkas ataupun syarat-syarat yang berkaitan dengan perizinan investasi dapat dilakukan melalui aplikasi ini sehingga dapat mempermudah investor di Kota Dumai. 
3) Sumber Daya Manusia

DPMPTSP Dumai membutuhkan teknisi atau konsultan yang ahli di bidang IT untuk membuat dan mengembangkan aplikasi SIAPI. Pegawai yang ahli dalam pengembangan aplikasi di DPMPTSP Kota Dumai belum memadai. Pihak DPMPTSP Kota Dumai tidak membuat tim khusus untuk aplikasi SIAPI. Sehingga tidak ada sarana, prasarana dan sumber daya manusia yang fokus untuk pengembangan aplikasi SIAPI sebagai penunjang terlaksananya aplikasi SIAPI. Sedangkan untuk menjalankan aplikasi SIAPI, DPMPTSP Kota Dumai hanya menyediakan satu orang pegawai untuk mengoperasikan aplikasi SIAPI.

Dari uraian penjelasan di atas dapat disimpulkan bahwa pengelolaan aplikasi SIAPI belum optimal karena sumber daya manusia yang di miliki oleh DPMPTSP Kota Dumai belum memadai. Yang mana ketiga hal tersebut merupakan penunjang terlaksananya aplikasi SIAPI. Semestinya pihak Dinas Penanaman Modal dan Pelayanan Terpadu Satu Pintu Kota Dumai, menyediakan sumber daya manusia yang ahli dalam bidang teknologi sehingga sistem yang di terapkan di Dinas Penanaman Modal dan Pelayanan Terpadu Satu Pintu Kota Dumai dapat dijalankan dengan baik. Misalnya pembaharuan sistem yang ada di aplikasi SIAPI dan sistem lainnya yang diterapkan di Dinas Penanaman Modal dan Pelayanan Terpadu Satu Pintu Kota Dumai dapat dilakukan oleh tenaga ahli dari pihak Dinas Penanaman Modal dan Pelayanan Terpadu Satu Pintu sendiri tanpa melibatkan pihak ketiga.

\section{4) Anggaran}

Anggaran untuk biaya aplikasi SIAPI tidak dianggarkan. Aplikasi SIAPI di luncurkan pada akhir tahun 2019, kemudian awal tahun 2020 Indonesia mengalami wabah pandemic Covid19. Yang mana pandemi ini merupakan wabah berbahaya yang dapat menyebar dengan cepat, sehingga pemerintah pusat maupun pemerintah daerah melakukan berbagai cara dan upaya untuk menghadapi pandemic ini. Semua instansi pemerintah turut andil dalam mencegah penyebaran virus Covid-19 ini dengan mengalihkan anggarannya untuk kepentingan pencegahan virus Covid-19.

Begitu juga DPMPTSP Kota Dumai. Ketika terjadinya wabah Covid-19 pemerintah DPMPTSP Kota Dumai mengalihkan sebagian anggaran untuk percepatan penanganan Covid-
19 yang disebut rekoposing anggaran. Karena pengalihan anggaran tersebut, DPMPTSP Kota Dumai meminimalisir pengeluaran anggaran untuk sistem dan aplikasi yang diterapkan di DPMPTSP Kota Dumai. Sehingga berimbas kepada aplikasi SIAPI. Anggaran untuk mengupgrade aplikasi SIAPI diberhentikan sementara yang menyebabkan menunggaknya pembayaran aplikasi SIAPI kepada pihak Playstore.

\section{PENUTUP}

Berdasarkan hasil penelitian yang diperoleh maka inovasi pelayanan melalui Aplikasi Potensi Investasi di Dinas Penanaman Modal dan Pelayanan Terpadu Satu Pintu Kota Dumai belum efektif dan maksimal. Hal tersebut dikarenakan aplikasi SIAPI belum sesuai dengan indikator-indikator teori inovasi Rogers yaitu kesesuaian, inovasi berupa aplikasi sudah memanfaatkan teknologi sesuai perkembangan zaman, namun fitur yang disediakan belum sesuai dengan keinginan pengguna. Dilihat dari indikator kerumitan, inovasi SIAPI memiliki kerumitan yang mengharuskan pengguna untuk melakukan proses administrasi secara manual sehingga sama saja dengan sistem konvensional sebelum adanya aplikasi SIAPI. Dan juga aplikasi SIAPI sulit ditemukan di Playstore sehingga menyulitkan pengguna untuk dapat menggunakan aplikasi SIAPI.

\section{DAFTAR PUSTAKA}

Arikunto, Suharsimi. (2010). Prosedur Penelitian: Suatu Pendekatan Praktik. Jakarta: PT. Rineka Cipta.

Bungin, Burhan. (2008). Metodologi Penelitian Kualitatif. Jakarta: Raja Grafindo Persada.

Creswell, W. J. (2010). Research Design Pendekatan Kualitatif, Kuantitatif, dan Mixed, ed. ke-3. Terjemahan: Achmad Fawaid. Yogyakarta: Pustaka Pelajar.

Dharmanu, I. P. (2017). Modernisasi dan Inovasi dalam Pelayanan Publik Melalui E-Government di Kota Denpasar. Jurnal ADHUM,VII(2), 93 . https://doi.org/10.1017/CBO978110741 5324.004

Dhewanto, Wawan. (2013). Manajemen 
Inovasi: Peluang Sukses Menghadapi

Perubahan. Yogyakarta: ANDI

Yogyakarta.

Hardiansyah. (2018). Kualitas Pelayanan Publik: Konsep, Dimensi, Indikator, dan Implementasinya. Gava Media.

Herdiansyah, Haris. (2011). Metodologi Penelitian Kualitatif. Jakarta: Salemba Humanika.

Ida Wantri Hastuti, S. S. (2018). Analisis Inovasi Pelayanan Perizinan Jemput Bola di Dinas Penanaman Modal dan Pelayanan Terpadu Satu Pintu (DPMPTSP) Kabupaten Semarang

Idrus, Muhammad. (2009). Metode Penelitian Sosial Pendekatan Kualitatif dan Kuantitatif. Jakarta: Erlangga.

Kurniati, N. (2019). Inovasi Pelayanan Perizinan Investasi Di Kota Mataram. Jesya (Jurnal Ekonomi \& Ekonomi Syariah), 2(2), 71-81. https://doi.org/10.36778/jesya.v2i2.72

Kurniawan, A. D. (2015). Inovasi Pelayanan Publik (Studi Deskriptif tentang Inovasi Pelayanan Surat Izin Usaha Perdagangan (SIUP) di Badan Penanaman Modal dan Perizinan Kabupaten Lamongan). Kebijakan Dan Manajemen Publik, 3(3), 167-176.

Nur Fitriana, D. (2014). Inovasi Pelayanan Publik BUMN (Studi Deskriptif tentang Inovasi Boarding Pass System dalam Meningkatkan Kualitas Pelayanan Kereta Api PT KAI di Stasiun Gubeng Surabaya). Kebijakan Dan Manajemen Publik, 2(2), 1-10. Retrieved from http://www.journal.unair.ac.id/download -fullpapers-kmp3c8840fbddfull.pdf

Pangestu, W. R. (2016). Inovasi Pelayanan One Stop Service ( Studi Peningkatan Kualitas Pelayanan Paspor Di Kantor Imigrasi Kelas I Khusus Surabaya ). Jurnal Kebijakan Dan Manajemen Publik, 4, 1-7.

Pransiska, E. (2018). Inovasi Pelayanan Publik Dalam Perspektif Best Practice (Praktik
Terbaik) Pada Dinas Penanaman Modal dan Pelayanan Terpadu Satu pintu (DPMPTSP) Kota Pekanbaru. 53(9), 1689-1699.

https://doi.org/10.1017/CBO978110741 5324.004

Putra, M. T. (2016). Evaluasi Partisipasi Masyarakat dalam E-Government Pelayanan Publik di Kabupaten Boyolali. Jurnal Publik, 4(1).

Putra, R. M. D. (2018). Inovasi Pelayanan Publik di Era Disrupsi (Studi Tentang Keberlanjutan Inovasi E-Health di Kota Surabaya) Journal of Chemical Information and Modeling, 53(9), 16891699.

https://doi.org/10.1017/CBO978110741 5324.004

Rasyidin, A. W. (2017). Analisis Pelayanan Publik di Dinas Penanaman Modal dan Pelayanan Terpadu Satu Pintu Kota Palopo

Ronnyta, R. V. (n.d.). Inovasi Pelayanan Perizinan Melalui Si-Imut Pada Dinas Penanaman Modal dan Pelayanan Terpadu Satu Pintu (DPMPTSP) Kota Semarang 1-15.

Suwarno, Yogi. (2008). Inovasi di Sektor Publik. Jakarta: STIA-LAN Press. 